\author{
Ivan Gryshchenko \\ Anatoliy Danylkovych \\ Kyiv National University of Technologies and Design \\ Nemirovich-Danchenko Street, 2 \\ Kyiv 01011, Ukraine \\ Tel.:+38044-280-05-12 \\ E-mail: knutd@knutd.com.ua
}

\begin{abstract}
In order to raise the economic efficiency of industrial enterprises, there had been suggested the methodology of identifying the optimal needs of resources of leather raw materials. The efficiency of developed methodology is based on the economicmathematical model which takes into consideration all the categories of natural raw materials, the variants of technological treatment, the technical opportunities of an enterprise and permits to identify the consolidated profit from the sale of manufactured products.
\end{abstract}

Keywords: methodology, leather raw materials, economic-mathematical model, optimizing the raw stuff resources.

JEL Classification: P 42

\title{
STATEMENT OF A PROBLEM
}

The strategic aim of the state structural and innovative politics is to increase the economic efficiency of innovative technologies of industrial enterprises on the basis of providing the systematic modernization of industrial production, its relevance to the contemporary demands of scientific and technological advance and integration into the world economy. At the present stage the fundamental tasks of the development of light industry include: raising the quality and competitiveness of domestic products, the expansion of their positions, first of all, at the home market by means of improving and developing the resource-saving technologies of manufacture and mastering the new kinds of production, transmission to the innovative model of development and intensive renewal of production facilities.

The state and development of the light industry in Ukraine is influenced with a great amount of external and internal factors (The results of industrial work in Ukraine for January-December 2011; Tarasenko, 2010) which are to be studied for complex, systematic solution of all problems taking into account branch peculiarities and trends of world economy development under the conditions of globalization. The state of enterprises of light industry substantially depends on the development of agricultural sector, namely livestock sector - the supply of leather raw materials and wool, crop production - the supply of cotton, flax, 
hemp, engineering industry and others. The systemic development factors of economic potential of light industry enterprises (Tarasenko, 2010) should include such conditions and factors: natural and climatic, ecological, social and economic, market, political conditions and factors, resources, state regulation, the development of society and its scientific and technological level.

One of the substantial resource-intensive and natural-climatic factors which influence the activity of light industry enterprises, namely leather, fur, footwear, fancy leather and textile branches, is to provide enterprises with raw materials. In its turn, the situation in agriculture directly influences the supply of light industry enterprises with raw materials of necessary quality and in relevant amount which currently hinders its development. According to research results, from 1990 till 2012 the production of crop sector was shortened as well as the total number of cattle, pigs, horses, sheep and goats. Besides the production decrease, during the last years we can observe considerable worsening of the qualitative features of raw stuff. At the same time there is also a trend of decreasing the weight of different kinds of livestock (The official site of State Statistics Service of Ukraine; Statistical Yearbook of Ukraine 2007).

It is worth mentioning that animals' skins are specific resources of leather sector which is used for production of leather materials of different destination - for the top and bottom parts of footwear, clothes, haberdashery and other kinds. Ready-made leather materials which are made from different kinds of raw materials are characterized with different qualitative properties and yield from square. It depends upon the number of factors. First of all, these are breeds of cattle, gender and age, the group according to its weight and the district of laying-in of raw stuff.

In order to determine the technological properties of cattle skins and the main factors that influence the quality of leather raw stuff and received materials, there had been conducted research. According to the results of this research, it was found that the better properties belonged to the pair skins of bulls of following cattle breeds: The Ukrainian Grey, Hereford and Chernihiv, as well as hybrids obtained by crossing red steppe and black-motley cattle (Tarasenko, 2001). Besides, the results of research have shown that the heaviest and thickest skins with the lowest yield from square of leather material for footwear cover are skins of Ukrainian Grey bulls, but the received material possesses high quality according to a set of physic-chemical parameters; the good yield of pair raw stuff, weight, square and the grade of quality of ready leather materials belongs to Chernihiv breed cattle; the best one turned out to be the raw stuff from Central and North regions of Ukraine (the average grade of quality accounts to 99.2 and $99.5 \%$ ), namely from Vinnytsya, Zhytomir, Kyiv, Luhansk and other regions. As for the influence of means of procurement and preserving on the quality of raw materials, the raw stuff received from meat processing and packing factories possesses much better quality properties comparing with procurement organizations.

The resources of raw materials considerably determine the production potential of the most enterprises of light industry, and their limitedness makes them treat the supplies economically, develop new technologies (Danylkovych and the staff of authors, 2011) and use other alternative kinds of raw materials. Because of season slaughter of cattle and the irregularity of delivering the leather raw materials and great distribution of cattle skins according to weight and structure, leather enterprises should maintain its two/three-week reserves at raw materials plants. For this reason, there is the problem of optimizing the usage of raw stuff and obtaining the maximum profit by leather industry enterprises. Taking into consideration that it is possible to use the same kind of raw stuff for producing leather materials of different destination, it is suggested to make the optimal choice of raw stuff depending on the range of ready materials that are being released.

It is also worth pointing out that the same kind of raw stuff can be processed by different means for producing the different range of leather materials, as the existing technologies provide for several production ways of obtaining materials from different kinds of raw stuff (Danylkovych, 2009). At the same time some or other production way of raw stuff treating provides for obtaining certain kind of leather material 
(Zhuravskiy, 1996). Depending on its destination, it is possible to use different parts and layers of material (State Standard 382-76, 1976).

\section{THE OBJECTIVES OF OUR RESEARCH}

In order to raise the efficiency of the work of enterprises, it is necessary to develop methodology of optimizing the needs of resources of leather raw materials for producing materials of different destination on the basis of economic-mathematical model. Such a task can be solved both for a separate enterprise and the group of leather factories (branches). Output data for this should include information about: the need in leather raw stuff for materials of different destination, availability of raw stuff resources of different breeds and groups according to weight from different sources, different variants of production ways of obtaining leather material for footwear top (there are known norms of yield of ready leather of different destination for each way).

While creating the model, the result of theoretical search and practical research of authors became the methodological approach as for the choice of optimal variant of using the resources of leather raw stuff and its purchase in order to obtain the maximum profit that provides for taking into account such constraining conditions:

- taking into account the need in leather material of each kind while processing the raw material according to different ways of target destination;

- taking into account the limitedness of resources of leather raw material: expenses of each kind of raw stuff according to all the variants cannot exceed available resources;

- opportunity to change one kind of leather material for another one in case of insufficient yield of material of certain kind (Ispiryan, 1974).

\section{THE MAIN RESULTS OF RESEARCH}

It is determined that the main stages of suggested methodology of assessing the alternative variants of using the raw material for production of leather material for footwear top are:

1. Determining the amount of leather raw material according to the kinds and districts of laying-in in order to take into consideration these factors while forming the batches of raw material. It is necessary to adhere to the condition that the amount of one-time treatment of raw material cannot exceed the determined amount of a batch.

2. Determining the resources of raw material in each district of its stocking under the condition of taking into account that the total amount of raw stuff of all kinds cannot exceed the available resource.

3. The yield of leather material from square of each kind using different production technologies and taking into account the changeability of available resource of raw stuff should provide the planned release of enterprise production.

4. Determining the amount of maximum profit of an enterprise from treatment of all kinds of raw materials according to all production ways and taking into account the condition that the amount of treating the raw stuff according to each production way should be positive.

In order to choose the optimal variants of using the resources of leather raw stuff and its purchase, it is suggested the following linear economic-mathematical model. The task determines the amount of 
leather raw stuff of $\alpha \mu v$ - kind, which is delivered from source $\mu$ with batch $\pi$ and is treated according to $s$ - variant of target destination for providing the maximum profit. The following marks are used for its compact structure:

$\alpha \quad-$ the index of the kind of leather raw stuff, $\alpha=1,2 \ldots, l$;

$\mu \quad-$ the district (country) of raw stuff stocking, that means the source of its delivery, $\mu=1,2, \ldots, k$;

$v \quad$ - the breed of cattle, which raw stuff is being procured, $v=1,2, \ldots, q$;

$s \quad-$ the index of technological way of production from the given leather raw stuff of different destination;

$\pi \quad$ - the number of a batch, $\pi=1,2, \ldots, r$;

$\beta \quad-$ the index of a kind of leather material, $\beta=1,2 \ldots, m$;

$\eta \quad$ - the index of changeability variant of leather material (is being carried out in case of insufficient yield of the Material of a certain kind), $\eta=1,2 \ldots, t$;

$P_{\text {auvas }}$ - the variant $s$ of the target usage of raw stuff of $\alpha$-kind from $\mu$ - district, which is provided with the batch $\pi$, from animals' skins of $v$-breed;

$3_{\alpha \mu v \pi}$ - the expenses on purchasing the unit of raw stuff of $\alpha$ - kind in $\mu$ - district from raw stuff of breed $v$ of a batch $\pi, d_{\beta \alpha \mu v s}$ - yield of leather material of $\beta$ - kind from the unit of raw stuff of $\alpha \mu \nu \pi$ - kind, which is used according to the variant $s$ of target destination;

$a_{\beta \eta} \quad$ - the coefficient which defines the ratio of the yield of leather material which is being changed according to variant $\eta$;

$\overline{x_{\eta}} \quad$ - the intensity of using the $\eta$ - variant of changeability;

$Q_{\alpha \mu v}$ - the maximally possible amount of raw stuff of $\alpha v$ - kind, which can be purchased by a leather plant in $\mu$ - source of raw stuff (district, country, region);

$R_{\alpha \mu \nu \pi}$ - the batch of raw stuff of $\alpha \mu \nu$ - kind, which can be purchased for price $3_{\alpha \mu \nu \pi}$;

$A_{\beta} \quad$ - the necessary yield of leather material of $\beta$ - kind;

$C_{a \mu v a s}$ - the profit of an enterprise as a result of the yield of leather material from the unit of raw stuff according to the production way $P_{\alpha \mu v \pi s}$;

$X_{a \mu v \pi s}$ - the intensity of using the production way $P_{a \mu v \pi s}$

The economic-mathematical model includes:

1. The amount of leather raw stuff of $\alpha$ - kind, purchased in $\mu$ - source by batch $\pi$ for price $3_{a \mu v \pi}$ cannot exceed the determined size of the batch:

$$
\sum_{s=1}^{n} \tilde{O}_{\alpha \mu v \pi s} \leq R_{\alpha \mu v \pi}
$$

2. The aggregate amount of the raw stuff of $\alpha v$ - kind which is purchased in $\mu$ - source of raw stuff cannot exceed the available resources:

$$
\sum_{\pi=1}^{r} \sum_{s=1}^{n} X_{\alpha \mu v \pi s} \leq Q_{\alpha \mu v}
$$

3. The aggregate yield of leather material of $\beta$ - kind, obtained from treating the raw stuff according to different production means $P_{a \mu v \pi s}$, taking into account the possibility of changeability, should be equal to the determined amount of its production:

$$
\sum_{\alpha=1}^{l} \sum_{\mu=1}^{k} \sum_{v=1}^{q} \sum_{\pi=1}^{r} \sum_{s=1}^{n} d_{\beta \alpha \mu \nu \tau s} \cdot X_{\alpha \mu \nu \pi s} \pm \sum_{\eta=1}^{t} a_{\beta \eta} \cdot \overline{X_{\eta}}=A_{\beta}
$$


4. The target function of the task is the aggregate profit from treating the all kinds of raw stuff according to all production ways which should be maximal:

$$
L=\sum_{\alpha=1}^{I} \sum_{\mu=1}^{k} \sum_{v=1}^{q} \sum_{\pi=1}^{r} \sum_{s=1}^{n} C_{\alpha \mu v \pi s} \cdot \tilde{O}_{\alpha \mu \nu \pi s} \rightarrow \max
$$

5. The amounts of treating the raw stuff according to each production way should be positive:

$$
\tilde{O}_{\alpha \mu v \pi s} \geq 0
$$

Let us consider the structure of the compact economic-mathematical model in the matrix-vector form. According to the rows, the economic-mathematical model consists of two groups of blocks: the resources of leather raw stuff and the material for top of footwear. The block of the first group is equal to equation (2), the second one - (3). Each block of the second group includes the kinds of leather material of one kind and destination. From top to bottom the blocks of materials are situated in order of decreasing their value, and within one block - in order of decreasing their groups of thicknesses. The model includes all existing groups of thicknesses of leather material. If there is no need in material of the certain group of thicknesses, the relevant element according to the vector $P_{0}$ is equal to zero.

Within one block leather materials are situated in order of decreasing the groups of thicknesses. The model should include the leather materials of all kinds. If there is no need in materials of $\beta$ - kind, the relevant element $A_{\beta}$ of vector $P_{0}$ is equal to one.

The economic-mathematical model of such structure allows to solve the task of optimal using the available resources of raw stuff, taking into account not only the weight of skins, value and district of stocking, but also the distinctive features of raw stuff depending on breeds and kinds of cattle. The economic-mathematical model includes all production ways of treating the raw stuff which are different with receiving different range of ready leather materials. That promotes raising the efficiency of production, competitiveness of leather materials on the basis of economical usage of limited raw stuff resources and is one of the directions of providing the competitive advantage according to expenses.

Let us consider solving the task on the example of closed joint-stock company "VOZKO". The table 1 of closed joint stock company "VOZKO" features consumer demand on chrome materials from cattle raw stuff which are in popular demand at the Ukrainian market and are being exported abroad.

Table 1

Consumer demand on leather materials of chrome tanning from cattle raw stuff at closed joint - stock company "VOZKO"

\begin{tabular}{|c|c|c|c|}
\hline $\begin{array}{c}\text { The kind of leather material for } \\
\text { the top of footwear of chrome } \\
\text { tanning }\end{array}$ & $\begin{array}{c}\text { Name and thickness of material, } \\
\mathrm{mm}\end{array}$ & $\begin{array}{c}\text { Demand on material, } \\
\text { mln.dm }{ }^{2}\end{array}$ & $\begin{array}{c}\text { Profit from } \\
1 \mathrm{~m}^{2} \text { of material, } \\
\text { hryvna }\end{array}$ \\
\hline 1 & 2 & 3 & 4 \\
\hline Ordinary material & College, $1,4-1,6$ & 25,37 & 14,30 \\
\cline { 2 - 4 } & Bugskaya, $1,2-1,4$ & 16,09 & 18,90 \\
\cline { 2 - 4 } & Veleten, $1,2-1,4$ & 25,38 & 21,28 \\
\cline { 2 - 4 } & Gryozy, $1,0-1,2$ & 22,18 & 23,25 \\
\cline { 2 - 4 } & Nubuk, $0,9-1,1$ & 21,17 & 23,22 \\
\cline { 2 - 4 } & Hama, $0,9-1,1$ & 30,5 & 18,36 \\
\hline
\end{tabular}




\begin{tabular}{|l|c|c|c|}
\hline \multicolumn{1}{|c|}{1} & 2 & 3 & 4 \\
\hline \multicolumn{1}{|l|}{ Total of ordinary material } & 140,69 & 119,31 \\
\hline Elastic material & Crazy Horse, 1,4-1,6 & 12,23 & 18,00 \\
\cline { 2 - 4 } & Crazy Horse, 1,2-1,4 & 14,013 & 18,00 \\
\cline { 2 - 4 } & Lada, 1,2-1,4 & 9,05 & 20,45 \\
\cline { 2 - 4 } & Kaskad, 1,2-1,4 & 13,014 & 21,00 \\
\cline { 2 - 4 } & Mykolayivska, 1,2-1,4 & 10,5 & 18,00 \\
\cline { 2 - 4 } & Nappita, 0,9-1,2 & 16,39 & 18,36 \\
\hline \multicolumn{2}{|c|}{} & 75,197 & 113,81 \\
\hline \multicolumn{2}{|l|}{ Total of elastic material } & 215,887 & 233,12 \\
\hline
\end{tabular}

The economic-mathematical model of optimizing the usage of resources of leather raw materials and its purchases includes vectors-operands $P_{\alpha \mu \nu \pi s s}$, vectors-operators $\overline{X_{\eta}}$ and unit vectors $P_{\alpha}^{v}$ which amount to additional variables $V_{a}$.

The elements of vectors-operands are the norms of yield of ready material from the unit of leather raw stuff of $\alpha$ kind of $v$ breed of cattle from the district $\mu$ of raw stuff stocking that is being treated according to production way $s$ by the party $\pi$, and in the block of resources of raw stuff - the element +1 (in the row that is italicized for relevant raw stuff according to a certain production way). The vectors-operators $\overline{x_{\eta}}$ reflect the changeability among different ways of leather materials.

The model provides for the usage of two production ways of treating the leather raw stuff into ready material- the production of ordinary material for the top of footwear and elastic material on the basis of chrome tanning (accordingly, $s=1$ and $s=2$ ). Besides, taking into account the natural limitedness of the resources of raw stuff and traditional for closed joint-stock company "VOZKO" sources of receipts, there had been considered the opportunity of delivering the raw stuff from Mykolayiv and Odessa regions (accordingly $\mu$ $=1$ and $\mu=2$ ). The average price of raw stuff which is being stocked in Odessa region taking into account the quality of the raw stuff of light and middle weights: bull-calf, bull and heifer raw materials amount to 11.92 hryvnas $/ \mathrm{kg}$, for heavy raw materials $-10.33 \mathrm{hryvnas} / \mathrm{kg}$, accordingly in Mykolayiv region amounts to 10.90 hryvnas $/ \mathrm{kg}$ and 9.40 hryvnas $/ \mathrm{kg}$. The data on the availability of raw materials of different cattle breeds in Mykolayiv and Odessa regions are given in the table 1.

Table 2

The resources of leather raw materials of different breeds of cattle in Mykolayiv and Odessa regions

\begin{tabular}{|c|c|c|c|}
\hline \multirow{2}{*}{$\begin{array}{c}* \\
\text { Kind of raw stuff, } \alpha\end{array}$} & Breed of cattle, $v$ & \multicolumn{2}{|c|}{$\begin{array}{c}\text { Available resources of raw materials, thousands } \\
\text { of tonnes, in the region }\end{array}$} \\
\cline { 2 - 4 } & & Mykolayiv & Odessa \\
\hline $\begin{array}{c}\text { Bull light, } \\
\alpha=1\end{array}$ & Ukrainian Grey, $v=1$ & 1,0 & 2,06 \\
\cline { 2 - 4 } & Charolais, $v=2$ & 2,6 & 0,97 \\
\hline $\begin{array}{c}\text { Bull heavy, } \\
\alpha=2\end{array}$ & Hereford, $v=3$ & 0,9 & 0,65 \\
\hline \multirow{2}{*}{$\begin{array}{c}\text { Heifer light, } \\
\alpha=3\end{array}$} & Limousin, $v=4$ & 1,1 & 1,71 \\
\hline Bull-calf, $\alpha=4$ & Znernihiv, $v=5$ & 1,2 & 0,9 \\
\cline { 2 - 4 } & Simmental, $v=7$ & 0,9 & 1,59 \\
\hline Total & Black-motley, $v=8$ & - & 1,29 \\
\hline
\end{tabular}


Solving this task allowed to obtain the optimal solution on the opportunities of treating the leather raw stuff at the closed joint-stock company "VOZKO". The maximal profit amounted to $33.698 \mathrm{mln}$. hryvnas for $215.887 \mathrm{mln}$. square decimeters of leather material, at the expense of better usage of raw stuff there had been achieved the growth of profit for $5.068 \mathrm{mln}$. hryvnas comparing with the virtual profit of the enterprise. Using the suggested model provides the opportunity of solving the problem of delivering and using the raw stuff, the choice of sources of its delivery by means of the most optimal way.

\section{CONCLUSIONS}

There had been developed the methodology of optimizing the raw stuff resources on the basis of suggested economic-mathematical model of optimizing the resources of leather raw stuff in the production of relevant materials. The developed compact model in matrix-vector form provides for all the categories of raw stuff, variants of its treating, technical opportunities of an enterprise and allows determining the maximal total profit from treating all kinds of raw materials. The efficiency of developed methodology of optimizing the raw stuff resources for producing leather materials is tested on the example of obtaining the maximal profit by the industry enterprise while producing two kinds of materials using the raw stuff of cattle of different breeds and the sources of their delivery. The suggested economic-mathematical model of methodology of optimizing the treatment of raw stuff resources can be used for raising the efficiency of work of other industrial enterprises.

\section{BIBLIOGRAPHY}

Підсумки роботи промисловості України за січень-грудень 2011 року//http://ukrlegprom.org.ua/ua/statistika_minstat_ukraiini/pidsumki_roboti_promislovosti_ukraiini_za_sichen_gruden_2011_roku.html

Тарасенко I. О. Сталий розвиток підприємств мегкої промисловості : теорія, методологія, практика : [монографія] / I. О. Тарасенко. - К. : КНУТА, 2010. - 390 с.

Офіційний сайт Аержавного комітету статистики України [ЕАектронний ресурс] / Режим доступу : www. ukrstat.gov.ua

Статистичний щорічник України за 2007 рік / [за ред. О. Г. Осауленка]. - К. : Консультант, 2008. $-571 \mathrm{c}$.

Тарасенко I. О. Вплив якості сировини на якість шкіри та формування асортименту / I. О. Тарасенко // Вісник Технологічного університету Поділмя. - Хмельницький: ТУП, 2001. - № 1. - Ч.2 (29). - C. 214-217.

Екологічно орієнтовані технології виробництва шкіряних та хутрових матеріалів Аля створення конкурентоспроможних товарів : монографія. Ч. I : Екологічно орієнтовані технології виробництва шкіряних та хутрових матеріалів / А. Г. Аанилкович, В. І. Аіщук, В. П. Плаван [та ін.] ; за ред. А.Г. Аанилковича. - К. : Фенікс, 2011. - 438 с.

Аанилкович А. Г. Технології переробки основних виАів сировини на шкіри різного цільового призначення // Технологія і матеріали виробництва шкіри : навч. посібник / А. Г. Аанилкович, О. Р. Мокроусова, О. А.Охмат ; піл реА А. Г. Аанилковича. - К. : Фенікс, 2009. - С. 369-516

Журавський В. А. Технологія шкіри та хутра / В. А. Журавський, Е. Є. Касьян, А. Г. Аанилкович : піАручник. - К. : АААПУ, 1996. - 744 с 
ГОСТ 382-76. Сырье кожевенное. Сортирование Аля промышленной переработки. ВвеА. с 01.01.1977. - М. : Иза-во стандартов, 1976. - 23 с.

Испирян Г. П. Математические методы в планировании и управлении на предприятиях мегкой промышленности / Г. П. Испирян, В. А. Рожок. - К. : Техніка, 1974. - 299 с. 